\title{
Atlantic Universities \\ Geoscience Conference \\ 2019
}

\section{ABSTRACTS}

October 24-26, 2019

$69^{\text {TH }}$ Annual Conference Hosted by:

Faribault Geology Club, St. Francis Xavier University

Antigonish, Nova Scotia

Abstracts from the Atlantic Universities Geoscience Conference (AUGC) are published annually in Atlantic Geology. Such publication provides a permanent record of the abstracts, and also focuses attention on the excellent quality of the oral presentations and posters at the conference and the interesting and varied geoscience topics that they cover.

Although the abstracts are modified and edited as necessary for clarity and to conform to Atlantic Geology format and standards, the journal editors do not take responsibility for their content or quality.

THE EDITORS 


\begin{abstract}
Acid rock drainage and potential arsenic concentration of natural and disturbed environments in the Meguma terrane, Nova Scotia, Canada
\end{abstract}

\section{Alison BARKHOUSE}

\section{Department of Earth Sciences, St. Francis Xavier University, Antigonish, Nova Scotia B2G 2W5}

Historic gold mining in Nova Scotia started in the early 1860s and lasted for 80 years, giving rise to over 60 goldproducing districts. Most of the gold mining in the province occurred in the southern mainland in the metasedimentary rocks of the Meguma terrane. The first indication of a significant problem in the area was recognized in 1976 when a man living in Waverley, home to a former operating gold mine, was diagnosed with chronic arsenic intoxication. Since this time, Nova Scotia has implemented a provincial multidisciplinary task force to investigate the occurrence of arsenic in Nova Scotian wells. While many of the studies conducted look at the concentrations of arsenic in drilled wells, this study is devoted to looking at arsenic concentrations of surface waters. Specifically, this study will compare the upstream and downstream concentrations of arsenic from former gold mining operations to utilize natural water gradients in which the water upstream of the mine would produce samples that resemble natural erosion and oxidization whereas samples downstream from the mines would be contaminated with Acid Rock Drainage (ARD) and thus contain heavy metals such as arsenic. The goals of this project are to determine if the arsenic present in the sample areas are distinctively a result of the mining processes that have occurred decades ago or if the arsenic has always been present as a result of the local bedrock geology and made available through natural erosion. [Oral presentation]

Permafrost coast sensitivity to air temperature and storm influence on Pullen Island, Northwest Territories, Canada

\section{Bay Berry, Dustin Whalen, and Michael Lim}

Department of Earth Sciences, Dalhousie University, Halifax, Nova Scotia B3H 4R2

Thaw-related erosion presents a unique problem for investigating the effects of changing weather trends on coastal dynamics along the Canadian Beaufort Sea; warming temperatures not only affect erosion indirectly by increasing energy to storms, but also have a direct influence on thaw rates. Two predominant failure mechanisms are identified for this study: failure of intact frozen blocks, attributed to undercutting from wave action, and slumping, a gravity driven movement of active layer sediments with the potential to form sprawling thaw complexes through rapid, retrogressive headwall retreat. Pullen Island, one of the outer islands of the Mackenzie Delta, exhibits both block failure and slumping along fairly constrained cliff sections, allowing the investigation of relationships between weather trends and erosion rates with regard to specific failure mechanisms. We use aerial imagery and ground survey data to show that mean erosion rates increased progressively from $0 \pm 4.8 \mathrm{~m} / \mathrm{a}$ in 1947 to $12 \pm 0.3 \mathrm{~m} / \mathrm{a}$ in 2018, accompanied by an increase in the variability of erosion rate across the study area. The increased heterogeneity of the cliff retreat rate is likely a result of different magnitudes of response to changing weather trends depending on erosive mechanism, and thus the morphological differences (such as cliff height and ground ice occurrence) which prescribe the mechanism. When erosion via each mechanism was compared to the historical weather record, we found that the correlation with summer air temperature was stronger in areas where slumping was dominant than in block failure areas. Similarly, the correlation with storm duration was stronger in areas where block failure was the dominant mechanism compared to slumping areas. These data indicate that storm duration has the greatest impact on these ice-rich permafrost coasts and most acutely on areas undergoing block failures, whereas air temperature has a greater impact on slump-dominated areas than elsewhere along the coast. Based on observations at Pullen Island, we can expect coastal erosion rates across the Beaufort Sea area to increase and diversify in response to the current and projected climate trends. [Poster presentation]

Detailed seismostratigraphy and well log analysis of the Saglek Basin, offshore Labrador, Canada, using regional seismic reflection profiles and intersecting wells

\section{Alex Bugden* ANd Kim Welford}

Department of Earth Sciences, Memorial University of Newfoundland, St. John's, Newfoundland and Labrador A1B 3X5

The Labrador Sea is an ocean basin located off the coast of northern Labrador in which continental margins were formed by the rifting of the North American craton during the Cretaceous and early Cenozoic. Within this ocean basin are several major sedimentary basins, of which the most northern, the Saglek Basin, is the focus of this study. The basin is vast with an area exceeding $100000 \mathrm{~km}^{2}$. During the early Cenozoic, a trans-continental river system, known as the paleo-Bell River system, deposited much of the sedimentary fill present in the basin today. Sedimentary sequences in the northern part of the basin are underlain by Eocene tholeiitic drift basalts that thin progressively 
to the south where gneissic rocks become the basement. Little hydrocarbon exploration work has been done in the region; however, a drilling program was undertaken in the 1970s-1980s and a total of nine wells were drilled. Of these nine wells, this project focuses on the Snorri J-90 and Karlsefni A-13 wells, as they intersect seismic lines that were shot in 2001 by TGS. TGS has kindly made these seismic lines available for interpretation. The objective of this thesis is to combine seismic interpretation, well log analysis, and rock physics modelling to enhance knowledge of the evolution of the Saglek Basin. The well log analysis and seismostratigraphy will be performed using data provided by TGS and C-NLOPB. Core analysis of the wells will also be undertaken if the core is available and has not deteriorated to the point where it is no longer useful. If the core is intact, rock properties will be derived from the core samples and RokDoc software will be used to combine the core results with the geophysical well logs to generate improved synthetic seismograms. These seismograms will be imported into Petrel software to improve the well ties and the overall seismostratigraphic analysis. Ultimately, the evolution of the Saglek Basin, in light of the thesis results, will be interpreted. [Poster presentation]

${ }^{*}$ Winner of the Canadian Society of Exploration Geophysics Award for best presentation of a geophysics-related paper

The first discovery of tetrapod trackways from the Pennsylvanian (Westphalian C), Plymouth Member of the Stellarton Formation, Stellarton Basin, Nova Scotia, Canada Logan M. Cormier, Matt R. Stimson, Olivia A. King,
and Janey McLean

Department of Geology, Saint Mary's University, Halifax, Nova Scotia B3H 3C3

The Maritimes Basin of Atlantic Canada is known for discoveries of tetrapod skeletons and their footprints that range from Early Mississippian to Early Permian. These Late Paleozoic tetrapod fossils are found at several locations in Nova Scotia, most notably Joggins, East Bay, and Horton Bluff. The first evidence for tetrapods from the Stellarton Basin was made by Sir John William Dawson, who discovered a partial skull of Baphetes planiceps. Following Dawson's early 20th century discovery, no further evidence of tetrapods (trace fossils or body fossils), have been encountered in the Stellarton Basin. Fossil material from the Stellarton Basin is dominantly comprised of plant material and coal balls, which have been recovered through the town extensive coal mining history.
A new discovery of tetrapod footprints from the Pennsylvanian (Westphalian C) Stellarton Formation represents the first tetrapod ichnofossil to be discovered in the Stellarton Basin. The Stellarton Formation is divided into seven members. The trackways in this study are preserved in grey sandstone of the Plymouth Member that has been interpreted to represent fluvial deposits. At the study area, the trackway-bearing sandstone is exposed in a private aggregate quarry and conformably overlies lacustrine shale of the Westville Member which outcrops just east of the quarry along East River. The tetrapod tracks are preserved in convex hyporelief and are here identified as the ichnotaxa Limnopus heterodactylus. Limnopus heterodactylus is characterized as having footprints with tetradactyl manus and pentadactyl pes with short rounded digits, and is larger than $2 \mathrm{~cm}$. Limnopus heterodactylus has traditionally been interpreted to represent the trackways of temnospondyl amphibians well known from timeequivalent rocks elsewhere in Nova Scotia. The trackways presented here are the first evidence of temnospondyls in the Stellarton Basin. The underlying Westville Member preserves the first record of invertebrate ichnofossils in the Stellarton Basin, including abundant samples of Monomorphicnus sp. and Rusophycus carbonarius that are interpreted to be made by crustaceans. The low-diversity ichnofossil assemblage presented above represents the first ichnological study in the Stellarton Basin documenting a marginal lacustrine depositional environment populated by temnospondyls and crustaceans. [Oral presentation]

\section{Paleoenvironment reconstruction of the Cambrian- Ordovician boundary of western Newfoundland, Canada, using petroleum biomarkers and carbon isotope chemostratigraphy}

\section{John Mishael Dooma*, Karem Azmy, Anirban Chowdhury, ANd Todd G. Ventura}

\section{Department of Geology, Saint Mary's University, Halifax, Nova Scotia B3H 3C3}

For this study, we have investigated marine carbonate and shale deposited as rhythmites from the lower Shallow Bay Formation and upper Green Point Formation of the Cow Head Group spanning the Cambrian-Ordovician boundary in western Newfoundland. Eighteen carbonate and shale samples were collected and processed for their hydrocarbon biomarkers. The resulting solvent extracts were analyzed using comprehensive two-dimensional gas chromatography-mass spectrometry (GC $\times \mathrm{GC}-\mathrm{MS})$. Several petroleum biomarkers such as n-alkanes, acyclic isoprenoids, steranes, hopanes, and aromatic hydrocarbons 
were quantified. These biomarkers are used as parameters to reconstruct the paleodepositional conditions of the depositional environment, degree to which biodegradation has effected the preservation of the resulting sedimentary organic matter, and thermal maturation of the extractable hydrocarbons. Pristane/Phytane $(\mathrm{Pr} / \mathrm{Ph})$ ratios of the sediment samples range from $(\sim 1.3$ to $\sim 3.4)$, indicating that the organic matter was deposited under oxic to suboxic conditions. A comparison of $\mathrm{Ph} / \mathrm{n}-\mathrm{C}_{18}$ and $\mathrm{Pr} / \mathrm{n}-\mathrm{C}_{17}$ suggests the organic matter is derived from mixed Type II/ Type III kerogen. The sediments also contains $\mathrm{C}_{27}, \mathrm{C}_{28}, \mathrm{C}_{29}$ $\alpha \beta \beta$ - and $\alpha \alpha \alpha$-steranes $24(S+R)$ and $\alpha \beta$ - and $\alpha \beta$ - diasteranes in which the $\mathrm{C}_{29}$ stigmasteranes dominate. Gammacerane, formed from the biological precursor tetrahymanol found in ciliated detritivores that commonly thrive in marine stratified water columns was also detected. Gammacerane Index (GI) values are low, ranging from $\sim 0.82$ to $\sim 3.5$, indicating that the water column was not stratified during sediment deposition. The ratio of 25-norhopane and $C_{30} \alpha \beta$ $+\mathrm{C}_{31} \alpha \beta 22(\mathrm{~S}+\mathrm{R})$ hopanes shows minimal biodegradation on the samples. Maturation of source rocks was assessed by monitoring the ratio of trisnorneohopane (Ts) and trisnorhopane (Tm) as well as $\mathrm{C}_{31} \alpha \beta$ homohopane $\mathrm{S} /(\mathrm{S}+\mathrm{R})$. $\mathrm{Ts} /(\mathrm{Ts}+\mathrm{Tm})$ and $\mathrm{C}_{31} \alpha \beta \mathrm{S} /(\mathrm{S}+\mathrm{R})$ values are 0 to $\sim 0.68$ and $\sim 0.45$ to $\sim 0.54$, respectively. These low values indicate the organic matter in most of the samples is early to moderately mature. Samples with the highest range of $\mathrm{Ts} /(\mathrm{Ts}+\mathrm{Tm}) 0.57$ to 0.62 likely experienced the main phase of oil generation. The $\delta^{13} \mathrm{C}$ profile across Shallow Bay Formation and Green Point Formation shows alternation of positive and negative $\delta^{13} \mathrm{C}$ excursions (SPICE event, post-SPICE event, and HERB or TOCE event). Changes in organic matter ratios are observed by using steranes/hopanes (in \%) and $\mathrm{Pr} / \mathrm{Ph}$ ratios. Distinct negative shifts of values for the two parameters correspond to negative $\delta^{13} \mathrm{C}$ excursions during SPICE, postSPICE, and HERB events. At the Cambrian-Ordovician boundary, there is an inverse relationship between the two parameters (high steranes/hopanes percentage; low $\mathrm{Pr} / \mathrm{Ph}$ ratios) that may be linked to oxygen drawdown by increased microbial productivity in the water column that relates to redox condition at depth. [Poster presentation]

${ }^{*}$ Winner of the Canadian Society of Petroleum Geologists Award for the best petroleum geology-related presentation

\section{Melt and fluid inclusion systematics of the Cantung $\mathrm{W}(\mathrm{Cu}, \mathrm{Au})$ skarn deposit, Northwest Territories, Canada: modeling W enrichment and fluid composition in the adjacent Mine Stock intrusion}

\author{
Gabriel Gomez Garcia, Andrew Wagner, \\ Erin Adlakha, Jacob Hanley, Pilar \\ LeCUmberri-SANCHEZ, and Hendrik Falck \\ Department of Geology, Saint Mary's University, \\ Halifax, Nova Scotia B3H 3C3
}

The Cantung W ( $\mathrm{Cu}, \mathrm{Au})$ skarn deposit, Northwest Territories, Canada is a world-class calc-silicate skarn deposit hosted by the Cambrian Sekwi Formation limestone, near its contact with the Cretaceous Mine Stock monzogranite. The limestone was affected by the Mine Stock in three ways: (i) contact metamorphism during initial emplacement of the intrusion, (ii) magmatic fluids associated directly from the intrusion, and (iii) fluids that used the same pathways as the magma that formed late staged aplitic dykes. Skarn mineralization (scheelite) occurred from magmatic fluids derived either from the proximal intrusion or by latestage aplitic dykes. Previous work on the Mine Stock monzogranite, immediately below the E-zone orebody, identified coeval silicate melt and fluid inclusions, and zircon inclusions, in apatite. All which provide a unique opportunity to understand the enrichment in, and transfer of, metals between fractionated granitic melts and immiscible aqueous fluids responsible for the formation of the high-grade $\mathrm{W}$-skarn deposits.

Preliminary fluid inclusion petrography indicates very small ( $\sim 5 \mu \mathrm{m}$ wide) liquid-rich fluid inclusions with minor vapour bubble. This study will investigate the melt and fluid inclusion systematics of the apatite from the Mine Stock. A multi-microanalytical approach will be undertaken to determine the i) minimum entrapment temperatures, fluid composition and salinity using microthermometric analysis of the fluid inclusions, ii) major element composition including halogens of quenched melt inclusions to classify the melts, iii) temperature of apatite crystallization (i.e., inclusion entrapment) using electron probe microanalysis of biotite/apatite pairs for $\mathrm{F} / \mathrm{Cl}$ thermometry, and iv) temperatures of zircon crystallization via LA-ICP-MS using Ti-in-zircon thermometry. Results will be used to model P-T-X conditions during inclusion entrapment. Fluid inclusion data will be compared to the already established fluid inclusions systematics of the ore zone in order to constrain mineralizing fluid compositions and model processes of $\mathrm{W}$ enrichment in the granitic intrusions. [Poster presentation] 


\section{Storm frequency and extreme waves in Atlantic Canada}

\section{TAylor Gregory and Vittorio Maselli}

\section{Department of Earth Sciences, Dalhousie University, Halifax, Nova Scotia B3H 4 R2}

Canada's east coast has experienced more than 50 severe storms in less than a century. Most recently, the category 2 post-tropical cyclone Hurricane Dorian struck Atlantic Canada in early September 2019. Understanding how anthropogenic climate change will influence storm frequency and intensity in the future is crucial to design proper mitigation strategies and evaluate the risk of storm surges in the region. The results of climate models have been contradictory, and this often reflects the lack of historical storminess data to support the simulations. Critical information has been obtained by investigating lagoonal deposits. In this setting, extreme waves generated by hurricane winds can transport coarse-grained sediment eroded from the beach into areas where the background sedimentation is fine-grained, and past studies have been able to show a strong correspondence between sand-bed intervals and intense storm episodes. Here we want to test the hypothesis that shelfal basins offshore Nova Scotia, like the Emerald Basin, may record historical storminess in their deposits. Previous studies have suggested that storminduced extreme waves are able to re-suspend sediment in the upper slope of the basin, creating dense flows migrating downslope under the actions of gravity. This project aims to reconstruct paleo storms during the Late Holocene (last 5 000 years) by dating storm-driven sand-beds from sediment gravity cores retrieved in the Emerald Basin at a depth of 190 $\mathrm{m}$. Numerical models of coupled wind-ocean circulation will help assessing the minimum wave energy required to resuspend sediment, thus providing critical information on the intensity of past storm events. [Oral presentation]

\section{Examining $\mathrm{CO}_{2}$ sequestration potential and subsequent mineral carbonation in ultramafic rocks from the Baie Verte area, Newfoundland, Canada}

\section{Kayla Lawrence* and Penny Morrill}

Department of Earth Sciences, Memorial University of Newfoundland, St. John's, Newfoundland and Labrador A1B 3X5

As atmospheric carbon dioxide $\left(\mathrm{CO}_{2}\right)$ levels continue to rise due to anthropogenic influence, developing long term ways to capture and store $\mathrm{CO}_{2}$ are important for preventing accumulation in the atmosphere and further harm to the biological processes that take place on Earth. One possible long-term storage option is through carbon mineralization, a naturally occurring process that can sequester $\mathrm{CO}_{2}$ from the atmosphere and store it in the form of stable, solid carbonate minerals. This type of reaction happens naturally at sites of serpentinization due to the groundwaters that are present in these areas. Type I waters have a meteoric origin and are enriched in $\mathrm{Mg}^{2+}$ and $\mathrm{HCO}_{3-}$ ions, whereas Type II waters are rich in $\mathrm{Ca}^{2+}$ and $\mathrm{OH}^{-}$and develop when Type I waters are isolated from the atmosphere. In this study, we will use laboratory experiments to determine whether the ultramafic rocks collected in Baie Verte, Newfoundland, have the potential for carbon mineralization. The rock samples will be crushed, mixed with simulated Type I or Type II waters, and placed in the LI-COR flux chamber which will measure any change in $\mathrm{CO}_{2}$ gas concentration throughout the duration of the experiment. For each experiment, a total of four water samples will be taken, two at the start and two at the end, to determine any change in total ions, specifically $\mathrm{Mg}^{2+}$ and $\mathrm{Ca}^{2+}$, in solution and a change in the total inorganic carbon. [Poster presentation]

\section{${ }^{*}$ Winner of the Atlantic Geoscience Society Award for the best Environmental Science presentation}

The age and petrogenesis of the Donegal Batholith, Ireland: insights from titanite

\section{LAURen Macquarrie}

\section{Department of Earth Sciences, St. Francis Xavier University, Antigonish, Nova Scotia B2G 2W5}

Titanite geochronology can be a valuable tool in determining granite petrogenesis. Titanite is a common accessory mineral in granitic rocks and can incorporate uranium making it a useful mineral for uranium-lead dating. Most frequently, zircon is used for uranium-lead dating, but with its high crystallization temperature there is also a high possibility of inheritance from source rocks. Titanite can remain closed to lead up to temperatures of $750^{\circ} \mathrm{C}$, which is within the crystallization temperature range of most granites leading to a lower possibility of inheritance. As a result, titanite may retain a less complicated signal of the crystallization age. Titanite also incorporates trace elements (e.g., $\mathrm{Zr}$ ) into its crystal structure that reflect P-T conditions at the time of crystallization and can be used as a thermobarometer. This project focuses on titanite in granitoid rocks in the Donegal Composite Batholith of the Caledonide orogen in NW Ireland, specifically the older plutons (Main Donegal, Ardara, Fanad, and Thorr granites). The Donegal Batholith is composed of seven I-type plutons 
in total, ranging in composition from granite to gabbro, that intruded between ca. 435-400 Ma during the Caledonian orogeny. Although the Donegal Batholith is well mapped, the ages and duration of magmatism, the magma source(s), the relationship of magma production to mountainbuilding events, and the continuity of magma production remain poorly understood. Laser Ablation Inductively Coupled Plasma Mass Spectrometry will be used to obtain $\mathrm{U}-\mathrm{Pb}$ isotopic data and trace element data from titanite to help discern the age, composition and petrogenesis of the Donegal Batholith. [Oral presentation]

The mineralogy, paragenesis, and petrogenesis of the polymetallic (Co-Ni-As-Au) veins of the Nictaux Falls Dam occurrence in the Annapolis Valley, Nova Scotia, Canada

Natalie McNeil ${ }^{*}$, Nicole Kennedy, Erin Adlakha Mitchell Kerr, Geoff Baldwin, and John Wightman

Department of Geology, Saint Mary's University, Halifax, Nova Scotia B3H 3C3

The Nictaux Falls Dam occurrence (NFDO) hosts polymetallic veins (Co-Ni-As-Au) located in the spillway of the Nova Scotia Power Dam along the Nictaux River, Annapolis Valley, Nova Scotia. The mineralogy of the understudied polymetallic veins of the NFDO are investigated in order to describe their petrogenesis. Mineralization is restricted to fault-hosted quartz veins in the metamorphosed (greenschist facies) sedimentary rocks of the Silurian Kentville Formation, proximal to its contact with the Devonian South Mountain Batholith (SMB). Two styles of mineralization are identified: (i) laminated sulfarsenide-quartz veins, and (ii) quartz breccia veins containing sulfarsenide-mineralized wallrock clasts. The sulfarsenides are spatially associated with wallrock material (chlorite, biotite, rutile, REE-phases) and exhibit unidirectional zoning regardless of mineralization style: early euhedral arsenopyrite cores (50 to $100 \mu \mathrm{m}$ ) are overgrown by a succession of arsenopyrite to cobaltite to gersdorffite. Textural evidence suggests arsenopyrite cores are derived from the wallrock. Unidirectional zoning indicates settling of dense sulfarsenides in the fluid during mineralization. Compositional zoning could indicate the removal of Fe and Co from the mineralizing fluid through progressive sulfarsenide mineralization, or decreasing $\mathrm{pH}$. Late native $\mathrm{Au}(20 \mathrm{wt} \% \mathrm{Ag})$ occurs interstitial to gersdorffite rims of the sulfarsenide accumulations. Sulfur isotope analysis of the sulfarsenides and wallrock sulfides will be conducted in order to constrain the source of S.

Bulk rock geochemistry of the metasediment rocks and nearby gabbro and diabase show high $\mathrm{Co}$ and $\mathrm{Ni}(20-24$ and 31-34 ppm Co and 55-71 and 21-107 ppm Ni, respectively), suggesting these rocks as potential sources of metals. In the metasedimentary rocks, the $\mathrm{Co}$ and $\mathrm{Ni}$ is primary and hosted in chlorite and sulfides; however, in the mafic rocks the metals are associated with secondary actinolite and sulfides. Mafic enrichment of metals is suspected to be attributed to the fluid derived from the dehydration of metasedimentary rocks following the emplacement of the intrusive rocks. The metasedimentary rocks are therefore the ultimate source of metals of the NFDO. Zircon geochronology of the mafic rocks will be used to understand their timing with respect to the SMB and mineralization. [Oral presentation]

\section{*Winner of the Frank S. Shea Memorial Award for best economic geology presentation}

Thermobarometry of eclogite from the Nordøyane UHP domain, western Norway: hot enough to melt?

\section{Benjamin Myrer, Luke Hilchie, ANd RebecCa JaMieson}

\section{Department of Earth Sciences, Dalhousie University, Halifax, Nova Scotia B3H 4R2}

Melting of subducted continental crust at ultrahighpressure (UHP) conditions has been suggested to play a role in the exhumation of large UHP terranes, including the Western Gneiss Region (WGR) of Norway. The region was affected by UHP metamorphism at ca. 415-400 Ma resulting from collision of Baltica with Laurentia during the Scandian phase of the Caledonian orogeny. In the Nordøyane UHP domain, well exposed sections along the coasts of Haramsøya and Flemsøya are underlain by migmatitic orthogneiss that hosts eclogite bodies with a variety of mineral assemblages and textures. Previous work documented UHP conditions in coesite-bearing eclogite and evidence for melting of the host rocks during decompression but did not find evidence for melting at peak pressure. This study is designed to obtain thermobarometric data from eclogite to see if the peak pressure-temperature (P-T) conditions overlap with the range where UHP melting is possible. Petrographic and microprobe data were obtained from a representative sample (CB15-19) of massive, medium-grained eclogite from the large Ulla Fyr body. The eclogite-facies mineral assemblage comprises omphacite + garnet \pm biotite \pm rutile, locally overprinted by retrograde amphibole + plagioclase \pm biotite \pm orthopyroxene \pm clinopyroxene. Clinopyroxene-plagioclase symplectite is present along omphacite-garnet grain boundaries. Omphacite, rutile, zircon, apatite, orthopyroxene, and biotite are present as 
inclusions in garnet. Garnet-clinopyroxene Fe-Mg exchange thermometry applied to coexisting garnet-omphacite pairs has yielded preliminary $\mathrm{T}$ estimates of $900 \pm 50^{\circ} \mathrm{C}$ at 30 kbar. Zirconium-in-rutile trace-element thermometry gave similar results of $850 \pm 50^{\circ} \mathrm{C}$. These $\mathrm{T}$ estimates overlap with the fluid-present UHP melting field for intermediate to mafic bulk compositions. However, further work is needed to obtain additional $\mathrm{T}$ estimates and independent constraints on $\mathrm{P}$ from samples reflecting the range of eclogite-facies mineral assemblages and textures present in the study area. [Poster presentation]

\section{The mineralogy and petrogenesis of rare-element granitic pegmatites in northeastern Nova Scotia, Canada}

\section{Shae Nickerson}

\section{Department of Earth Sciences, St. Francis Xavier University, Antigonish, Nova Scotia B2G 2W5}

Northeastern mainland Nova Scotia hosts several rareelement granitic pegmatite bodies in the Meguma terrane. These pegmatites have received very little academic study, including the Lower Caledonia Pegmatite, which was discovered in 1999. The pegmatite is situated on the periphery of an elongate leucogranite named the Kelly Brook pluton. Both the pegmatite and the Kelly Brook pluton contain metasedimentary xenoliths of the Meguma Supergroup and all units are sheared due to dextral transpressive movement along the Minas Fault Zone during the late Devonian and Carboniferous. The pegmatite contains large quartz and $\mathrm{K}$-feldspar megacrysts along with plagioclase, muscovite, pyrite, tourmaline, garnet and high concentrations of beryl. The beryl crystals are randomly oriented and up to $5 \mathrm{~cm}$ in diameter and $>5 \mathrm{~cm}$ in length. The euhedral beryl is altered and contains inclusions of quartz, plagioclase, and muscovite. Quartz is recrystallized and deformed. $\mathrm{K}$-feldspar and plagioclase are also deformed. Muscovite is deformed, altered and occurs within small miarolitic cavities. Tourmaline only grew near the metasedimentary xenoliths, commonly with the c-axis oriented normal to the contact of the xenolith. Garnet is present in the pegmatite core as small, euhedral crystals. The granite is dated at ca. $375 \mathrm{Ma}$ and has recrystallized quartz, rotated microcline, sheared muscovite, plagioclase, chlorite, garnet, zircon and apatite.

Electron probe microanalysis and laser ablation inductively couple plasma mass spectrometry will be used to document the chemical composition of the pegmatite- and granite-forming minerals. Whole-rock geochemical data from the pegmatite, granite and host rock samples will aid in determining the processes that formed the rare-element pegmatite. Geochronological data will show the temporal relationship between the granite and the pegmatite. This data will characterize the mineralogy, petrography, age, geochemical composition, and classification of the pegmatite. Taken together the data will enable the interpretation of the pegmatite-forming processes and their relationship to the regional tectonic environment. [Oral presentation]

\section{Determination of Northwest Atlantic coastal isoscape}

\section{Rachel Noddle and Owen Sherwood}

\section{Department of Earth Sciences, Dalhousie University, Halifax, Nova Scotia B3H 4R2}

Input of excess nitrogen $(\mathrm{N})$ causes eutrophication and degradation of coastal marine ecosystems. In Nova Scotia, sources of $\mathrm{N}$ enrichment in coastal waters include sewage wastewaters, aquaculture, seafood processing, and agricultural runoff. These $\mathrm{N}$ sources have different $\mathrm{N}$ isotopic $\left(\delta^{15} \mathrm{~N}\right)$ signatures, which are incorporated into the tissues of organisms that inhabit the local environment. Mapping the spatial variability of $\delta^{15} \mathrm{~N}$ coastal organisms can therefore help identify sources of $\mathrm{N}$ into aquatic ecosystems. We used the filter-feeding blue mussel (Mytilus edulis), found in the rocky intertidal zone along the province's coastline, to characterize baseline $\delta^{15} \mathrm{~N}$ isoscapes. Mussels are ideal sentinel organisms for this study because they feed on particulate organic matter, integrating it into their tissues, preserving the biogeochemical variability of the base of the marine foodweb over periods of several months. Specimens of M. edulis were collected in triplicate (wherever possible) from each of the 21 different sites on the Atlantic and Northumberland coasts of Nova Scotia. Analysis of $\delta^{15} \mathrm{~N}$ was performed on the adductor muscles after isolating from the rest of the tissues and freeze-drying. Within-site variability among triplicate specimens is remarkably low (mean of standard deviations $=0.56 \%$ ). No significant difference in $\delta^{15} \mathrm{~N}$ was detected between the Northumberland coast (7.6 $\pm 1.3 \%$; $\mathrm{n}=6$ sites $)$ and Atlantic coast $(7.9 \pm 0.9 \%$; $\mathrm{n}=$ 15 sites). There was, however, a wide range in mean $\delta^{15} \mathrm{~N}$ between sites, for example, over a $14 \mathrm{~km}$ stretch of the Northumberland coast from Pictou Harbour (mean $\delta^{15} \mathrm{~N}$ $=9.24 \pm 0.42 \%$ ) to Melmerby Beach (mean $\delta^{15} \mathrm{~N}=5.74 \pm$ $0.29 \%$ ). This local variability in M. edulis $\delta^{15} \mathrm{~N}$ composition likely reflects the inputs of nitrogen sources specific to each area and may provide a useful screening tool for further investigations of $\mathrm{N}$ loading to the marine environment. Additional work using compound specific isotope analysis of amino acids will be used to refine our estimates of baseline $\delta^{15} \mathrm{~N}$ isoscapes independently of trophic fractionation. [Oral presentation] 


\section{Petrography of mafic rocks associated with polymetallic (Co-Ni-Au-As-Ag-Pb-Sb-Bi) mineralization in the Meguma terrane, Nova Scotia, Canada}

\author{
Ryan Parsons, Naomi Welt, Geoff Baldwin, \\ AND ERIN AdLAKHA \\ Department of Geology, Saint Mary's University, \\ Halifax, Nova Scotia B3H 3C3
}

Several polymetallic (Co-Ni-Au-As-Ag-Pb-Sb-Bi) vein occurrences outcrop in the northwestern Meguma Terrane, and appear spatially associated with mafic rocks (e.g., gabbro and diabase). This project is a petrographic study of the mafic rocks using a combination of field and hand specimen observations, optical microscopy, and scanning electron microscopy (SEM), in order to determine whether the rocks are genetically related to mineralization (e.g., as metal sources). These techniques will aid in determining the mineralogy of the rocks, including discrete mineral assemblages and their paragenetic sequence. Through compositional and textural analysis using SEM, Co and $\mathrm{Ni}$ rich phases (e.g., sulfides, ferromagnesian silicates, silicate and sulfide melt inclusions) will be identified to constrain their relative timing (e.g., primary vs. secondary). These data will be used to evaluate whether the mafic rocks supplied Co and $\mathrm{Ni}$ for mineralization, either during their crystallization or through post-crystallization hydrothermal alteration. Additionally, petrographic work will be used to identify minerals for radiometric dating in order to constrain the absolute timing of the mafic rocks and their age in relation to mineralization.

Representative gabbro and diabase spatially associated with these polymetallic occurrences have been sampled from three occurrences (Cape St. Marys and Lansdowne in Digby County, and Nictaux Falls in Annapolis County). Gabbroic rocks were also sampled from two prospective properties in the Annapolis County (Inglisville and Inglisville Mountain). All samples were collected from outcrop, with the exception of Inglisville and Inglisville Mountain. Although mafic rocks have been mapped at these properties by previous workers, no outcrop was found during field work; therefore, float was collected from the property. The mafic rocks are dominated by primary plagioclase and pyroxene, and contain variable amounts of sulfide minerals (pyrite and chalcopyrite). The rocks are texturally varied, from fine-grained to coarsegrained, and some exhibit ophitic to subophitic texture. Secondary alteration is variable and includes the alteration of pyroxene to actinolite, saussuritization, carbonation (calcite), silicification and sulfidation. Current work is in progress to further characterize these rocks and their role during the mineralization of the polymetallic vein occurrences. [Poster presentation]

\section{Characterization of apatite within the Mactung W ( $\mathrm{Cu}, \mathrm{Au})$ skarn deposit, Northwest Territories, Canada: implication for the evolution of skarn fluids}

\author{
Andree Roy-Garand, Erin Adlakha, Jacob Hanley, \\ Hendrick Falck, Pilar Lecumberri-Sanchez \\ Department of Geology, Saint Mary's University, \\ Halifax, Nova Scotia B3H 3C3
}

Skarn-hosted apatite from the Mactung deposit was characterized in order to understand skarn paragenesis, chemical evolution, and signatures of mineralizing fluids. Four generations of fluorapatite were identified. Type-i apatite occurs with detrital phosphate nodules. This apatite contains variable $\Sigma \mathrm{REE}+\mathrm{Y}(1314 \pm 821 \mathrm{ppm}, 1 \sigma, \mathrm{n}=78)$ and has negatively sloping chondrite-normalized $\mathrm{REE}+\mathrm{Y}$ $\left(\mathrm{REE}+\mathrm{Y}_{\mathrm{N}}\right)$ patterns with variable $\mathrm{LREE}_{\mathrm{N}} / \mathrm{HREE}_{\mathrm{N}}\left(\mathrm{La}_{\mathrm{N}} / \mathrm{Lu}_{\mathrm{N}}\right.$ $=27 \pm 30)$ and weak Eu anomalies $\left(\mathrm{Eu}_{\mathrm{N}} / \mathrm{Eu}_{\mathrm{N}}{ }^{*}=0.6 \pm 0.2\right.$; $\mathrm{Eu}^{*}=\mathrm{Eu}_{\mathrm{N}} /\left(\mathrm{Sm}_{\mathrm{N}}{ }^{*} \mathrm{Gd}_{\mathrm{N}}\right)^{0.5}$. The REE abundance in type-i apatite is similar to that of phosphate nodules. Both have similar REE abundances as phosphate nodules reported in correlative limestone elsewhere in the Selwyn Basin. These similarities suggest that type-i apatite is a recrystallization product of phosphate nodules, likely during isochemical contact metamorphism. Type-ii apatite occurs in anhydrous prograde skarns and show high $\Sigma \mathrm{REE}+\mathrm{Y}$, and flat $\mathrm{REE}+\mathrm{Y}_{\mathrm{N}}$ patterns (e.g., $\Sigma \mathrm{REE}+\mathrm{Y}=17194 \mathrm{ppm} ; \mathrm{La}_{\mathrm{N}} /$ $\mathrm{Lu}_{\mathrm{N}}=3.5 ; \mathrm{n}=31$ ) with negative $\mathrm{Eu}$ anomalies (e.g., $\mathrm{Eu}_{\mathrm{N}} /$ $\left.\mathrm{Eu}_{\mathrm{N}}{ }^{*}=0.1\right)$. Hydrothermal type-iii apatite is associated with quartz-scheelite veins, which cross-cut prograde skarn. This apatite contains very high $\Sigma \mathrm{REE}+\mathrm{Y}(7752 \pm 496 \mathrm{ppm}, \mathrm{n}=$ 3) and bowl-shaped REE $+Y_{N}$ patterns, corresponding to low MREE $\left(\mathrm{La}_{\mathrm{N}} / \mathrm{Sm}_{\mathrm{N}}=8 \pm 0.3 ; \mathrm{Sm}_{\mathrm{N}} / \mathrm{Lu}_{\mathrm{N}}=0.3\right)$, and no $\mathrm{Eu}$ anomaly. Lastly, type-iv apatite occurs in hydrous retrograde skarns and shows bowl-shaped to negatively sloped $\mathrm{REE}+\mathrm{Y}_{\mathrm{N}}$ patterns, with low MREE content (e.g., $\mathrm{La}_{\mathrm{N}} / \mathrm{Sm}_{\mathrm{N}}=$ 10.2; $\mathrm{Sm}_{\mathrm{N}} / \mathrm{Lu}_{\mathrm{N}}=0.3 ; \mathrm{n}=17$ ) and positive $\mathrm{Eu}$ anomalies (e.g., $\mathrm{Eu}_{\mathrm{N}} / \mathrm{Eu}_{\mathrm{N}}{ }^{*}=14.3$ ). The paragenesis and distinct $\mathrm{REE}+\mathrm{Y}_{\mathrm{N}}$ patterns of hydrothermal type-ii, type-iii and typeiv apatite reflect the presence of two chemically distinct ore fluids. The first fluid formed type-ii apatite, prograde skarn and early, fine-grained scheelite. The second fluid was associated with late-stage quartz veining, retrograde skarn, and coarse-grained scheelite. The REE $+\mathrm{Y}_{\mathrm{N}}$ patterns of typeiii and type-iv apatite record a second fluid that underwent MREE fractionation. Preliminary cathodoluminescence images and trace element data from coeval scheelite show evidence for two generations of scheelite with distinct REE signatures, supporting the interpretation of two ore fluids. Trace element compositions of scheelite, are being investigated to constrain to further constrain the two ore fluids. [Oral presentation] 
Petrography, geochemistry, and economic minerals in core from three drill holes in the Faribault Brook area, western Cape Breton Island, Nova Scotia, Canada

\section{Michael Tamosauskas, Sandra M. Barr, AND Chris E. White \\ Earth and Environmental Science, Acadia University, Wolfville, Nova Scotia B4P 2 R6}

Details of the age, structure, and tectonic setting of the Jumping Brook Metamorphic Suite (JBMS) and associated economic mineral occurrences in the Faribault Brook area in the western Cape Breton Highlands remain enigmatic even after many decades of study. Recent work has indicated that the JBMS is of Cambrian age, in faulted contact with Proterozoic granitoid plutons and intruded by Early Ordovician, Silurian, and Devonian plutons. Mineral occurrences have been suggested to occur in the mainly metasedimentary Dauphinee Brook Formation, near its contact with the underlying mainly mafic metavolcanic Faribault Brook Formation. Lithological units are difficult to identify and correlate because of the effects of metamorphism and deformation. The area has been explored since the late 1800 s, and at least 15 significant sulphide occurrences are known, containing arsenopyrite, pyrrhotite, sphalerite, galena, and pyrite. Native gold and silver occurrences are also present in some occurrences, but no economically viable deposit has been found. Previous studies have suggested that the mineralization formed in a syngenetic polymetallic volcanogenic massive sulphide (VMS) system in MORBtype basalt associated with turbiditic sediments in a backarc basin, with additional evidence of epigenetic vein-related mineralization. Based on the postulated Cambrian age, the occurrences may correlate with Cambrian-Ordovician VMS deposits in Newfoundland and New Brunswick. This study focuses on holes RB-90-1, AMC-6-78, and GM-0908 , drilled to depths of 102,177 , and $50 \mathrm{~m}$, respectively. They were selected for study because of their locations in areas of significant known mineralization. In additional to visual logging, a KT-9 Kappameter instrument is being utilized to measure the magnetic susceptibility of the rocks at $10 \mathrm{~cm}$ intervals in each hole. Chemical analyses of the core are being made using a portable X-ray fluorescence spectrometer (pXRF) to identify mineralized sections and aid in identification and correlation of rock units between drill holes. Representative samples from each hole will be examined in thin section to determine metamorphic grade and protolith. Based on the petrographic features observed in thin section, samples will be selected for whole-rock analysis for major and trace elements, including rare-earth elements, using X-ray fluorescence and ICP-MS methods. Both metavolcanic and metasedimentary rocks will be sampled, as their geochemical signatures can provide evidence for mineralization as well as the tectonic setting during formation. Preliminary examination of the core has identified significant stratiform sulphide mineralization and well as in quartz-carbonate veins mainly along foliation. [Poster presentation]

\section{Isotopic analysis of ${ }^{65} \mathrm{Cu}$ and ${ }^{63} \mathrm{Cu}$ ratio for determination of native copper artifacts provenance using secondary ion mass spectrometry (SIMS)}

\section{Rosa Toutah, Jacob Hanley, and Katie Cottreau-Robins}

\section{Department of Earth Sciences, Dalhousie University, Halifax, Nova Scotia B3H 4R2}

It has long been presumed that the Lake Superior copper district was the primary source of copper for central and eastern North American indigenous peoples throughout pre-history. The premise of this assumption was the extensive copper deposits in this area, and similar stylistic attributes of copper artifacts found in the Lake Superior region compared to other archaeological areas. Analytical studies comparing the trace element chemistry of native copper sources and artifacts suggests that other sources (e.g., the Bay of Fundy region) may have been more important to the Wabanaki peoples of the Atlantic northeast. The aim of this study is to test this hypothesis, specifically, to uncover the source of copper present in many artifacts from the Maritimes Basin, which have been speculated to have originated from the Lake Superior deposits, but which may be more locally derived. Samples with known provenance will be analyzed for their ${ }^{65} \mathrm{Cu}:{ }^{63} \mathrm{Cu}$ isotopic ratios $\mathrm{R}\left({ }^{65} \mathrm{Cu} /{ }^{63} \mathrm{Cu}\right)$. The National Institute of Standards and Technology (NIST) copper standard \#976 $\left({ }^{65} \mathrm{Cu} 30.826 \pm 0.020,{ }^{63} \mathrm{Cu} 69.174 \pm\right.$ 0.020 ) will be used to calibrate (correct bias) the secondary ion mass spectrometer (SIMS) to be used in this study. SIMS will then be used to analyze the copper artifacts and using the artifact's $\mathrm{R}\left({ }^{65} \mathrm{Cu} /{ }^{63} \mathrm{Cu}\right)$ artifact the source location for the artifacts will be deduced. The project outline is as follows: (1) Use of National Institute of Standards and Technology copper standard \# 976 to correct bias of the secondary ion mass spectrometer. (2) Determination of a standardized $\mathrm{R}$ $\left({ }^{65} \mathrm{Cu} /{ }^{63} \mathrm{Cu}\right)$ for copper deposits with known origin from either the Lake Superior or the Maritimes Basin deposits. (3) Analysis of copper artifacts using secondary ion mass spectrometry. (4) Comparison of artifacts $\mathrm{R}\left({ }^{65} \mathrm{Cu} /{ }^{63} \mathrm{Cu}\right)$ in order to determine provenance of artifacts. [Poster presentation] 


\section{Petrology, age, and tectonic setting of the Gunshot Brook pluton, eastern Cobequid Highlands, Nova Scotia, Canada}

\section{Miguel Vaccaro ${ }^{*}$, Chris E. White, AND SANDRA M. BARR}

\section{Earth and Environmental Science, Acadia University, Wolfville, Nova Scotia B4P 2R6}

The Cobequid Highlands of northwestern mainland Nova Scotia have a complex tectonic history and are considered to form part of the southern margin of Avalonia. The area is generally interpreted to have developed as a series of volcanic arcs and back-arc basins on the periphery of Gondwana. The highlands are divided into two distinct fault-bound crustal blocks - the Jeffers block to the north and west, and the Bass River block to the south and east. The Gunshot Brook pluton is located on both sides of the Millsville fault, interpreted as a splay off the Rockland Brook fault that separates the Jeffers and Bass River blocks, and hence it is not clear to which block the pluton belongs. Previously published work combined with mapping for the present study show that the pluton intruded the ca. 750-735 Ma Mount Ephraim plutonic suite on its southern margin and the Dalhousie Mountain Formation of uncertain age on the north and northeast. An unpublished $\mathrm{U}-\mathrm{Pb}$ zircon age of ca. $605 \mathrm{Ma}$ was previously reported for the Gunshot Brook pluton, but an older $\mathrm{U}-\mathrm{Pb}$ zircon age of ca. $638 \mathrm{Ma}$ has also been obtained, and if correct, indicates that the Dalhousie Mountain Formation is older than other volcanic units in the Jeffers block. Based on petrographic study of about 100 samples collected in the present and related earlier studies, the Gunshot Brook pluton varies gradationally from tonalite to granodiorite and monzogranite, with minor co-mingled dioritic rocks, all cut by mafic and felsic dykes. Previously published and new whole-rock chemical data for about 50 samples display trends consistent with a comagmatic relationship among the tonalitic to monzogranitic rocks, with a compositional gap between those rocks and the dioritic rocks. The suite is calc-alkalic and likely formed in a continental margin subduction zone. Preliminary results indicate that no significant differences in rock types or chemical characteristics occur across the Millsville fault. Additional $\mathrm{U}-\mathrm{Pb}$ dating is in progress to attempt to resolve the ambiguity about the age of the Gunshot Brook pluton. [Oral presentation]

${ }^{*}$ Winner of the Science Atlantic Presentation and Communication Award for best overall presentation
Characterization of apatite-hosted silicate melt inclusions in magmatic rocks associated with the Cantung (W-CuAu) skarn deposit, Northwest Territories, Canada

\author{
ANdrew Wagner ${ }^{\star}$, Erin Adlakha, Kevin \\ Neyedley, Jacob Hanley, Hendrick Falck, \\ Pilar LeCUMBERRI-SANCHEZ \\ Department of Geology, Saint Mary’s University, \\ Halifax, Nova Scotia B3H 3C3
}

The Cantung (W-Cu-Au) skarn deposit, Northwest Territories, Canada, is one of the most significant highgrade $\mathrm{W}$ deposits in the world. The deposit occurs at the contact between Cambrian limestone (Sekwi Formation) of the eastern Selwyn Basin and the Cretaceous Mine Stock Pluton of the Tungsten-Tombstone magmatic belt in the northern Canadian Cordillera. The Mine Stock pluton consists of a sub-alkaline biotite monzogranite with coeval aplite, pegmatite, and lamprophyre dykes. Reduced W skarn deposits, such as Cantung, form through the interaction of W-rich, low salinity fluids with limestone country rock, producing a zoned array of calc-silicate skarn endowed in scheelite (calcium-tungstate). Mineralizing fluids for Cantung were either derived from the Mine Stock Pluton, or a related magmatic-hydrothermal system at depth, which is now preserved as the late-stage dykes and quartz veins. This study characterizes the apatite-hosted melt inclusions within the Mine Stock, in order to test whether the Mine Stock Pluton is the source of tungsten in the Cantung deposit. The melt inclusions occur predominately as crystallized (i.e., multi-phase), colorless and transparent inclusions, exhibiting a negative crystal shape, suggesting primary origin. Trace element concentrations of un-homogenized melt inclusions have been determined via laser ablation induced coupled plasma mass spectrometry (LA-ICP-MS). The inclusions have variable compositions, some of which are highly fractionated ( $\mathrm{Ti} / \mathrm{Zr}=1$ to $23 ; \mathrm{Zr} / \mathrm{Hf}=1$ to 29 ; $\mathrm{n}=60$ ), similar to previously reported whole-rock data for the late stage aplite dykes ( $\mathrm{Ti} / \mathrm{Zr}=3$ to $13 ; \mathrm{Zr} / \mathrm{Hf}=8$ to 17 ). The inclusions contain high and variable abundances of incompatible elements such as W (2 to $40 \mathrm{ppm}$ ), Sn (27 to $121 \mathrm{ppm}$ ), B (100 to $10271 \mathrm{ppm}$ ), Cs (10 to $1448 \mathrm{ppm}$ ), and Bi (11 to $399 \mathrm{ppm}$ ). Continued work includes homogenization experiments and electron probe microanalysis to quantify major elements abundances and volatiles in the melt. Whole-rock major and trace element abundances of the Mine Stock will also be determined via X-ray fluorescence and ICP-MS. This data will be used to model melt evolution and $\mathrm{W}$-enrichment and determine the crystallinity of the melt at the point of fluid saturation. [Poster presentation]

\footnotetext{
*Winner of the Imperial Oil Award for the best poster presentation
} 